\title{
Geometrical model for determining soil water content under sprinkler and raingun irrigation system
}

\section{D.K. Singh and R. Kishore}

Received : 14.01.2020; Revised : 01.02.2020; Accepted : 16.02 .2020

See end of the Paper for authors' affiliation

Correspondence to :

D.K. Singh

ICAR-Indian Institute of Farming Systems Research, Modipuram (U.P.) India Email: dharmendradksingh@ rediffmail.com
- ABSTRACT : In India, conventional surface irrigation methods to pressurized irrigation systems are in use. Pressurized irrigation including micro irrigation, sprinkler irrigation system as well as raingun are among the efficient irrigation techniques which may achieve field level application efficiency in the range of 60-95 per cent. These have vast potential and suitable for almost all field crops like wheat, gram, pulses, vegetables, cotton, soya bean, tea, coffee, and other fodder crops. The information on soil water content and wetted depth of wetted zone as well as duration of water application has importance towards uniformity and performance of irrigation system. The water content in geometry of soil wetted zone has importance in irrigation management to deliver required amount of water and nutrients to the plants to realize enhanced crop yield. Estimation of water content of wetted zone soil based on simplified geometry will serve purpose for most of field conditions and also reduces complexities encountered in numerical and analytical methods. A model based on simplified geometry and water volume balance was developed to simulate soil water content, wetting depths and duration of water application through sprinkler and raingun irrigation system. The geometry of wetted soil depth resulting from uniform and non-uniform water application through sprinkler and raingun was considered. With uniform water application the soil wetted zone could take shape of cylinder. However, with non-uniform water application, depth of wetted soil volume reduces towards the periphery of the wetted soil, that may be assumed as curved shape of ellipsoid or parabolic shape. Water volume balance method was considered in wetted geometry to develop model to estimate change in soil water content.

- KEY WORDS : Sprinkler, Raingun irrigation, Geometry of wetted zone soil, Model, Soil water content

- HOW TO CITE THIS PAPER : Singh, D.K. and Kishore, R. (2020). Geometrical model for determining soil water content under sprinkler and raingun irrigation system. Internat. J. Agric. Engg., 13(1) : 36-41, DOI: 10.15740/HAS/IJAE/13.1/36-41. Copyright@ 2020: Hind AgriHorticultural Society. 